\title{
Pengenalan Indahnya Keragaman Budaya Negeriku Melalui Media Pembelajaran Mobuya
}

\author{
Tri Syamsijulianto ${ }^{1}$, Arif Hidayat ${ }^{2}$, Mohammad Zainudin $^{3}$ \\ ${ }^{1}$ Pendidikan Dasar-Universitas Negeri Malang \\ ${ }^{2}$ Pendidikan Fisika- Universitas Negeri Malang \\ ${ }^{3}$ Keguruan Sekolah Dasar dan Prasekolah-Universitas Negeri Malang
}

\section{INFO ARTIKEL}

\section{Riwayat Artikel}

Diterima: 10-04-2019

Disetujui: 21-10-2020

\section{Kata Kunci:}

Mobuya learning media; cultural diversity; media pembelajaran Mobuya; keragaman budaya

\author{
Korespondensi: \\ Tri Syamsijulianto \\ Pendidikan Dasar \\ Universitas Negeri Malang \\ Jalan Semarang 5 Malang \\ E-mail: syamsijulianto17@gmail.com
}

\begin{abstract}
The Mobuya learning media stands for monopoly based culture. The Mobuya media teaching is a game based on students' ability to play and learn, its main content is question card that point to the HOTS. The purpose of this study to introduced the beautiful cultural diversity of country through the Mobuya learning media. Methods of media development in the study are ADDIE models (analyze, design, development, implementation, and evaluation). The results of the validation of qualified silabus scholars and material in the learning media fit valid or worthy criteria with small recensions. Results of the materials validation on the silabus validation sheet, scores obtained from the silabus validation valid or worthy criteria are used with small recensions. The location of the Mobuya scientific silabus learning aim higher level of thought ability or HOTS (Higher, Order, Thinking, Skills) posed. The validation of the media given to the validator of the learning media experts show good criteria so it can be continiue but with a few part that must be revised. The achievement assesment results given to teacher show the learning media can or deserve given to learners. The Mobuya learning media test, the learning media needs to be re-perfected so that in learning it is easy for learners to use.
\end{abstract}

ABSTRAK

\begin{abstract}
Abstrak: Media pembelajaran Mobuya merupakan singkatan dari monopoli berbasis budaya. Media pembelalajaran Mobuya merupakan permainan yang berlandaskan kepada kemampuan siswa dalam bermain dan belajar, konten utamanya berupa kartu pertanyaan yang terarah pada soal HOTS. Tujuan penelitian ini adalah mengenalkan indahnya keragaman budaya negeriku melalui media pembelajaran Mobuya. Metode pengembangan media dalam penelitian ini adalah model ADDIE (analyze, design, development, implementation, and evaluation). Hasil validasi ahli materi silabus kevalidan materi dalam media pembelajaran sesuai dengan kriteria valid atau layak digunakan dengan revisi kecil. Hasil validasi ahli materi pada lembar validasi silabus, skor yang diperoleh dari validasi silabus kriteria valid atau layak digunakan dengan revisi kecil. Letak dari scientific silabus media pembelajaran Mobuya, arahkan kemampuan berpikir tingkat tinggi atau HOTS (Higher, Order, Thinking, Skills) ditampakkan. Validasi media yang diberikan kepada validator ahli media pembelajaran menunjukkan kriteria baik sehingga dapat dilanjutkan, tetapi dengan beberapa bagian yang harus direvisi. Hasil penilaian angket yang diberikan kepada guru menunjukkan media pembelajaran dapat atau layak untuk diberikan kepada peserta didik. Uji coba media pembelajaran Mobuya, media pembelajaran perlu disempurnakan kembali sehingga dalam pembelajaran mudah untuk digunakan oleh peserta didik.
\end{abstract}

Tujuan pendidikan nasional dalam UU Republik Indonesia 20 Tahun 2003 Pasal 1 butir 1 menyebutkan bahwa "pendidikan sebagai cara sadar direncanakan untuk mewujudkan proses pembelajaran melalui suasana aktif agar dikembangkan potensi dirinya untuk mempunyai spiritual keagamaan diri untuk, kepribadian, kecerdasan, akhlak yang mulia, keterampilan untuk keperluan dirinya, maupun masyarakat, serta bangsa dan negara" (UndangUndang SISDIKNAS number 20 Tahun 2003). Tujuan itu dicapai di Indonesia telah menerapkan kurikulum baru, dimana tujuan utama dari perubahan tata konsep pendidikan di Indonesia ini adalah untuk memberikan pembelajaran bermakna, kreatif, inovatif, dan menyenangkan. Penerapan kurikulum 2013 diharapkan mampu memberikan pengaruh bagi proses pembelajaran. Pembelajaran menggunakan sebuah tema mengintegrasikan satu sama lainnya sehingga pembelajaran menjadi bermakna. Sebagian besar permasalahan tentang pendidikan berkaitan dengan upaya untuk 
menciptakan pendidikan yang bermutu, cerdas, dan berkarakter. Permasalahan yang sering kali terjadi pada proses pembelajaran yaitu tidak melibatkan peserta didik untuk dapat memberikan pembelajaran yang menyenangkan dan berpikir kritis melalui belajar sambil bermain. Wangid, Mustadi, Erviana, \& Arifin (2014) menyatakan bahwa untuk menciptakan kualitas peserta didik dapat dilakukan pembelajaran dengan terencana, efisien, intensif, dan efektif. Kualitas peserta didik yang rendah dikarenakan guru hanya memberikan pembelajaran yang monoton.

Fakta yang terjadi pada pembelajaran tematik bahwa pembelajaran yang diajarkan masih monoton. Lebih lanjut, hasil temuan dari Macdonald (2014) juga menjelaskan bahwa peserta didik kurang menyukai konteks yang dibelajarkan pada pembelajaran karena konten pembelajaran tematik yang diajarkan kurang menyenangkan. Hasil temuan dari Retnawati, Munadi, Arlinwibowo, \& Wulandari (2017) menunjukkan bahwa pada proses pembelajaran tematik hal sering kali dialami oleh guru berupa hambatan dalam memilih tema, guru mendapatkan permasalahan dalam mengelola waktu pelajaran serta ketersediaan fasilitas belajar itu masih terbatas. Pembelajaran yang terjadi karena pembelajaran tematik dibelajarkan secara keseluruhan dilihat melalui berbagai tema. Lebih lanjut, Sukini (2012) menyatakan bahwa kurang keterlibatan peserta didik pada pembelajaran sehingga belajar tidak menemukan pengetahuan sendiri dari yang dipelajarinya. Oleh karena itu, diperlukan pembelajaran yang mampu menumbuhkankembangkan pengetahuan dan pembelajaran yang menyenangkan.

Berdasarkan penuturan yang diberikan oleh guru kelas IV SDN 02 Beduai guru jarang menggunakan media pembelajaran karena keterbatasanan sarana dan prasana yang ada sehingga guru tidak pernah membuat media pembelajaran pada proses pembelajaran. Selain terbatasnya sarana dan prasarana serta kurang memadai ditambah dengan perlengkapan media tidak tersedia. Selain itu permasalahan lain yang kerap kali dialami guru di saat proses pembelajaran dikelas berupa kurang adanya inovasi yang dilakukan dalam merancang membuat media pembelajaran yang tidak memiliki biaya terlalu besar untuk membuat media pembelajaran yang menyenangkan. Kurang adanya inovasi guru dalam melaksanakan proses tersebut sehingga menciptakan pembelajaran yang bermakna.

Permasalahan lain pada proses pembelajaran, terutama pada pembelajaran tematik sub tema indahnya keragaman budaya negeriku. Pelestarian adat budaya lokal yang dilaksanakan oleh masyarakat setempat dimaksudkan memeliharanya dengan baik sampai ke anak untuk tetap menjaga budaya agar tidak lupa dengan asalnya (Sugeng, 2018). Pada proses pembelajaran guru jarang menggunakan media pembelajaran untuk mengenalkan tentang keragaman budaya yang ada sehingga mempersulit peserta didik untuk pembelajaran tematik. Fakta ini menunjukan bahwa masih kurangnya inovasi guru untuk mengembangkan media pembelajaran. Guru masih jarang yang menerapkan pembelajaran berbasis pada permainan sehingga dapat meningkatkan motivasi belajar siswa (Suhendrianto, 2017). Karakteristik yang dimiliki peserta didik usia sekolah dasar berupa media pembelajaran berbentuk permainan dapat digunakan sebagai cara untuk menyampaikan materi pembelajaran (Fitriyawany, 2013). Oleh karena itu, untuk mengurangi permasalahan yang terjadi pada pembelajaran di sekolah dasar diperlukan media pembelajaran berbentuk permainan agar dapat menciptakan pembelajaran yang menyenangkan dan memotivasi. Solusi yang ditawarkan oleh peneliti dengan media pembelajaran menggunakan permainan monopoli berbasis budaya.

Halloran \& Deale (2017) salah satu metode yang dapat digunakan sebagai alat pengajaran untuk mencoba melibatkan para siswa sepenuhnya dalam belajar berupa penggunaan permainan ataupun simulasi. Sehubungan dengan hal tersebut D'Astous \& Gagnon (2007) peneliti mengklaim bahwa permainan papan, seperti monopoli dapat dimainkan dan dimanfaatkan untuk media pembelajaran yang menyenangkan karena mampu meningkatkan pemahaman peserta didik sehingga memberikan siswa pemahaman lebih lama. Selain itu, permainan dengan menggunakan papan monopoli juga dapat dikembangkan dalam bentuk media pembelajaran monopoli berbasis budaya. Sejalan dengan itu, menurut Park (2017) menjelaskan permainan papan dapat menunjukan bahwa dengan bermain bersama-sama dapat meningkatkan keterampilan sosial peserta didik dan memberikan pembelajaran dua arah.

Media pembelajaran Mobuya menjadi solusi yang solutif dalam meningkatkan kemampuan peserta didik pada proses pembelajaran karena menggabungkan beberapa konsep ke dalam satu media pembelajaran. Peserta didik dapat mengenalkan budaya melalui belajar sambil bermain, berpikir kritis, belajar yang menyenangkan. Lebih lanjut, Oktavianti \& Ratnasari (2017) menyatakan bahwa penerapan monopoli budaya pada pembelajaran tematik mengajarkan kepada peserta didik untuk dapat belajar pada lingkungan individu dan kelompok dengan tujuan dapat menggali dan menemukan konsep dan makna materi itu sendiri. Mobuya dapat memberikan kontribusi yang positif dalam pengajaran tentang keberagaman budaya, memiliki dampak yang cukup luas untuk mengenalkan budaya daerah yang belum diketahui, dan mampu membelajarkan peserta didik sesuai dengan tuntutan pembelajaran di era modern ini. Uraian latar belakang tersebut menunjukkan bahwa media pembelajaran Mobuya sangat perlu untuk dikembangkan dalam memberikan pembelajaran bermakna pada peserta didik. Oleh karena itu, peneliti ingin mengembangkan media pembelajaran dengan judul Pembelajaran Tematik Materi Indanya Kergaman Budaya Negeriku Melalui Pengembangan Media Pembelajaran Mobuya Sekolah Dasar.

\section{METODE}

Penelitian ini merupakan penelitian pengembangan dengan model ADDIE (Analyze, Design, Development, Implementation, Evaluation) yang dikembangkan oleh Reiser dan Mollenda sejak 1990-an. ADDIE (Analyze, Design, Development, Implementation, Evaluation) merupakan model pengembangan yang sistematik dan prosedural. Menurut Yong, Chew, Mahmood, \& Arifin (2014) model pengembangan ADDIE (Analyze, Design, Development, Implementation, Evaluation) adalah proses instruksional dalam merancang dan mengembangkan kepelatihan. Sejalan dengan itu, Asist \& Sezer (2013) model 
ADDIE (Analyze, Design, Development, Implementation, Evaluation) merupakan jenis intruksional yang memiliki fokus pada pencapaian tujuan kelompok studi dengan perhatian bahwa strategi dan teknologi menjadi langkah untuk dipertimbangkan.

Menurut Branch (2009) langkah-langkah dari prosedur penelitian dengan menggunakan model ADDIE ada empat, yakni analyze, design, development, implementation, dan evaluation. Prosedur yang digunakan dalam pengembangan media pembelajaran Mobuya untuk pembelajaran tematik di sekolah dasar ditunjukkan pada gambar 1.

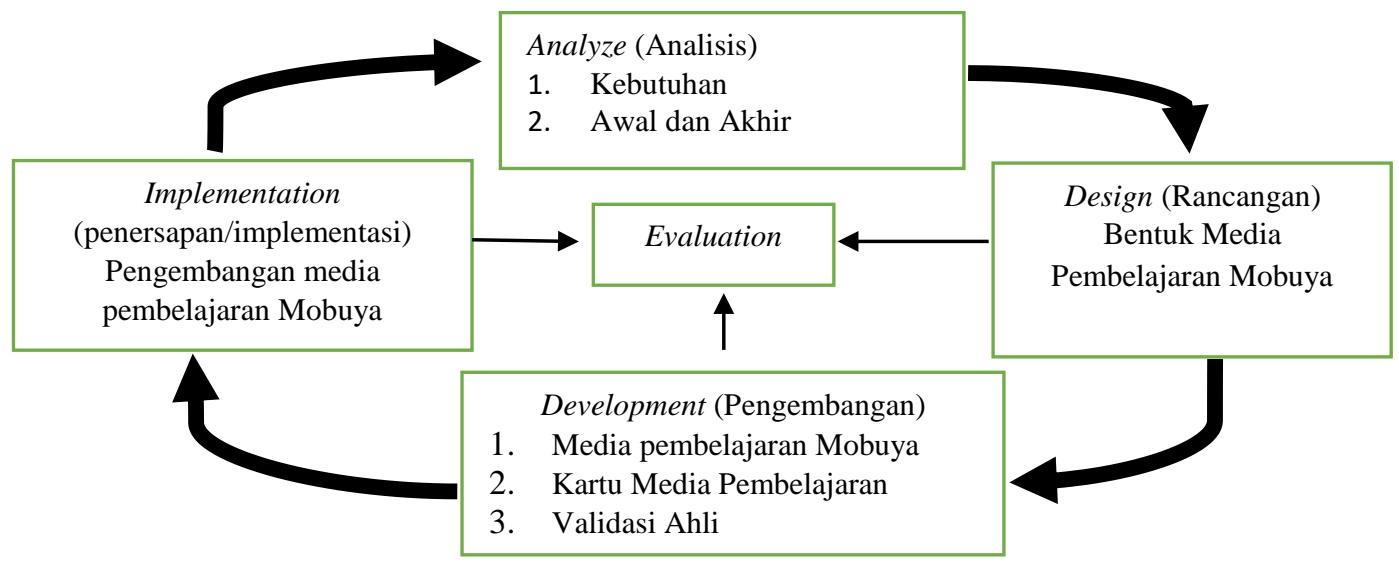

Sumber: Branch (2009)

Gambar 1. Model Penelitian dan Pengembangan ADDIE

Pemilihan model pembelajaran ADDIE (Analyze, Design, Development, Implementation, Evaluation) karena efisien untuk digunakan. Berdasarkan tahapan ADDIE dapat dipaparkan hal yang dilaksanakan pada proses penelitan ini sebagai berikut.

\section{Analyze}

Pada tahap analisis yang dilakukan berupa analisis kebutuhan. Tahap analisis kebutuhan, meliputi identifikasi kondisi di lapangan dan mengetahui kesejangan. Analisis kebutuhan didasarkan pada pencapaian kompetensi dasar, RPP, Silabus, dan materi pada proses pembelajaran. Tahap analisis awal dan akhir meliputi angket dan wawancara tidak terstruktur kepada guru. Analisis awal dan akhir dilihat dari analisis terhadap penggunaan media pembelajaran, data informasi, dan analisis anggaran yang digunakan dalam mengembangkan media.

\section{Design}

Pada tahap ini peneliti membuat sebuah desain atau rancangan media yang dikembangkan dengan melakukan analisis terhadap materi dan kompetensi yang akan dikembangkan. Kemudian menentukan konten yang akan dimasukan ke dalam media pembelajaran Mobuya. Racangan dimulai dengan mendesain media pembelajaran dengan photoshop, foto digunakan untuk membuat desain dari media pembelajaran Mobuya sehingga mudah untuk diaplikasikan pada tahap selanjutnya.

\section{Development}

Pada tahap ini dilakukan pengembangan media pembelajaran Mobuya yang telah dirancang. Tahap awal melakukan pengembangan papan media pembelajaran Mobuya dan mencetak stiker media untuk dipsangkan pada papan media pembelajaran Mobuya. Mencetak dadu untuk media pembelajaran Mobuya, selain itu pada tahap lain dicetak kartu untuk pembelajaran Mobuya. Pada tahap pengembangan lain dilakukan pengembangan materi untuk media pembelajaran Mobuya, selanjutnya dilakukan pengembangan silabus dan RPP serta buku panduan untuk penggunaan media pembelajaran Mobuya, serta pada tahap ini dilakukan validasi terhadap media pembelajaran Mobuya. Pada tahap pengembangan ini validasi media dilakukan oleh dua orang ahli media pembelajaran dan ahli materi.

\section{Implementation}

Pada tahap implementasi ini dilakukan uji coba terhadap media pembelajaran yang telah dirancang dan dikembangkan. Penerapan media pembelajaran dilaksanakan pada Sekolah Dasar Negeri 02 Beduai dengan jumlah peserta didik 24 orang.

\section{Evaluation}

Evaluasi media pembelajaran digunakan untuk melihat dari tahap implementasi media pembelajaran Mobuya.

HASIL 
Media pembelajaran Mobuya dikembangkan melalui tahap validasi ahli. Tahap validasi dilakukan pada proses pengembangan media pembelajaran Mobuya. Validasi materi yang divalidasi, yaitu RPP, media pembelajaran Mobuya yang dikembangkan, validasi terhadap silabus dan soal evaluasi yang digunakan dalam menerapkan media pembelajaran Mobuya, serta angket yang disebarkan pada peserta didik.

Validasi terhadap produk media pembelajaran berupa media pembelajaran Mobuya, RPP, silabus, materi, soal evaluasi, dan buku petunjuk penggunaan media pembelajaran. Pada proses validasi terhadap media pembelajaran dilakukan uji validasi terhadap hasil produk dari prototype media pembelajaran Mobuya dapat dilihat pada gambar 2 dan 3 .

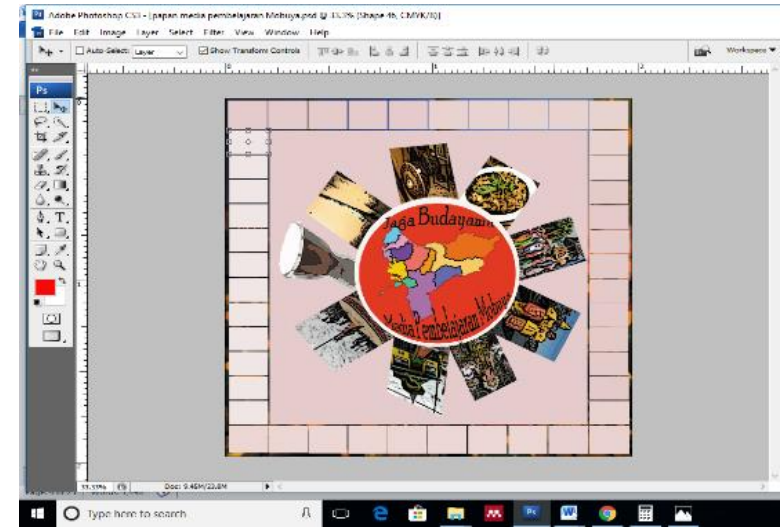

Gambar 2. Pemberian gambar kotak sebagai PetakPetak pada media pembelajaran Mobuya

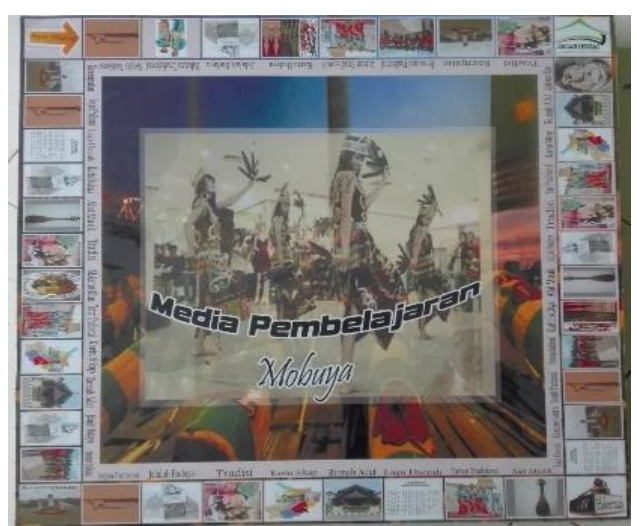

\section{Gambar 3. Desain Awal Media Pembelajaran}

Pada gambar 2 awal dalam proses pembuatan petak dalam media pembelajarn Mobuya, gambar itu menunjukkan petak satu sampai dengan petak terakhir. Selanjutnya, pada gambar 3 menunjukkan desain awal dalam media pembelajaran Mobuya.

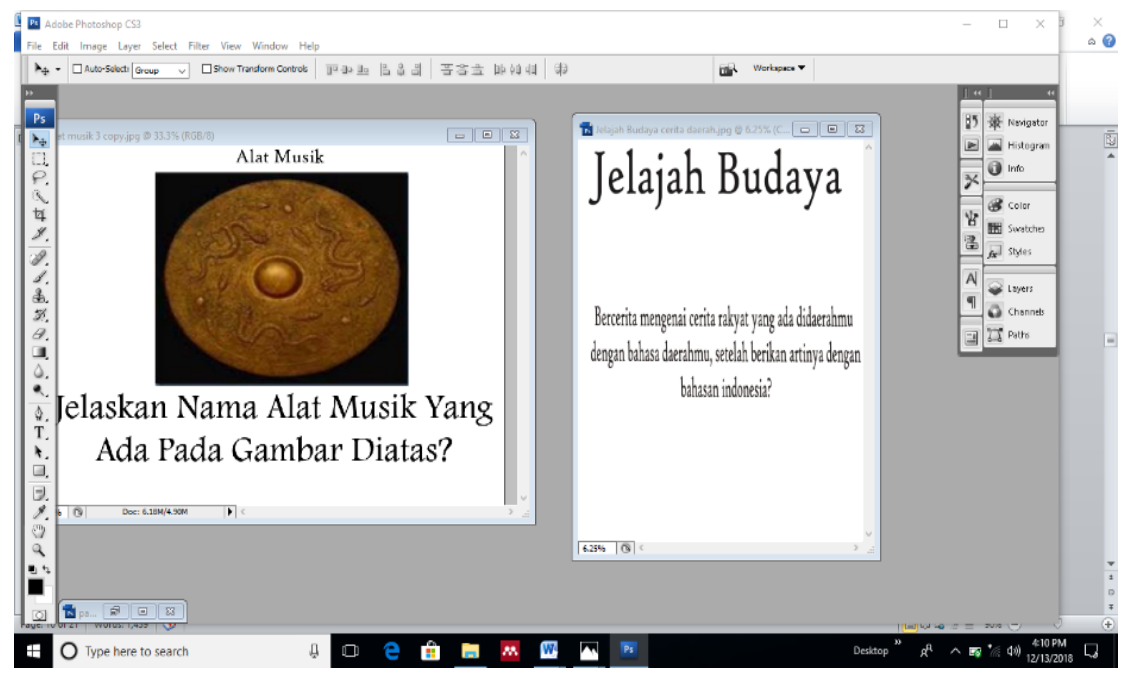

Gambar 4. Contoh Desain Akhir Kartu Pertanyaan pada Mobuya

Pada gambar 4, desain kartu media pembelajaran Mobuya yang dikembangkan. Pengembangan media pembelajaran dengan menggunakan kartu merupakan salah satu langkah alternatif untuk mempermudah peserta didik dalam melaksanakan proses dan mendapatkan konsep pembelajaran. 


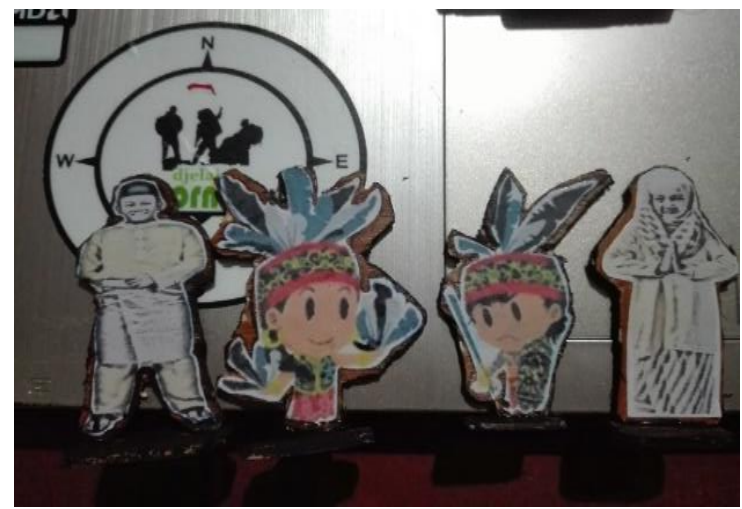

Gambar 5. Pion Media Pembelajaran Mobuya

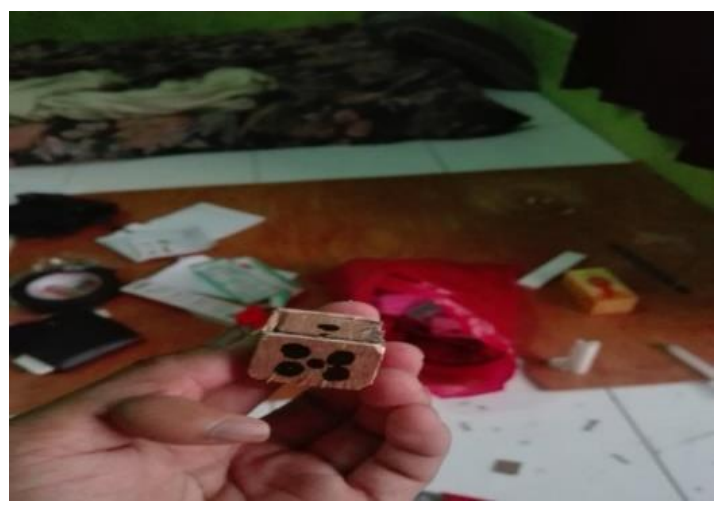

Gambar 6. Dadu Media Pembelajaran Mobuya

Gambar 5 dan 6 merupakan produk awal dari media pembelajaran Mobuya yang sebelum dilakukan validasi. Produk media pembelajaran Mobuya dibuat dengan bentuk sederhana. Prototype media pembelajaran dibuat melalui beberapa tahapan hingga membentuk media pembelajaran.

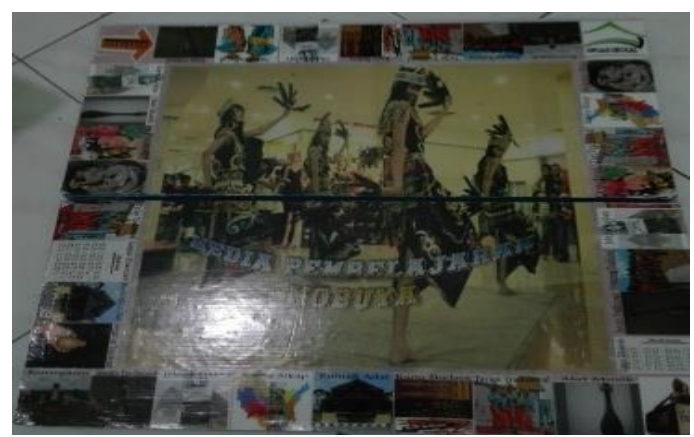

\section{Gambar 7. Desain Akhir Media Pembelajaran Mobuya}

Gambar 7 merupakan produk akhir dari media pembelajaran Mobuya. Media pembelajaran Mobuya mudah dibuka serta kartu mobuya juga disimpan didalam papan media Mobuya. Adapun validasi dilakukan oleh dua ahli, yakni ahli media pembelajaran dan ahli materi. Ahli media pembelajaran, yaitu dosen Teknologi Pembelajaran Universitas Negeri Malang dengan kualifikasi akademik S3. Sementara itu, ahli materi yaitu dosen FIP dengan fokus bidang kajiannya pada pembelajaran tematik dengan kualifikasi akademik S3. Hasil validasi ahli materi kevalidan materi dalam media pembelajaran sesuai dengan kriteria valid atau layak digunakan dengan revisi kecil. Selain memberikan hasil validasi, ahli materi juga memberikan komentar dan saran untuk media pembelajaran Mobuya. Komentar dan saran dari ahli materi yaitu panjang kalimat masih perlu disederhanakan, terasa berat untuk kelas IV, ukuran huruf/font diseragamankan, jangan terlalu kecil. Saran dan komentar dari ahli materi akan dipertimbangkan dalam implementasi media pembelajaran Mobuya sehingga media pembelajaran Mobuya dapat digunakan dengan layak. 
Hasil validasi ahli materi pada lembar validasi silabus, skor yang diperoleh dari validasi silabus kriteria valid atau layak digunakan dengan revisi kecil. Masukan dan saran untuk silabus yang digunakan, yaitu setiap kolom diberikan penenomoran sehingga lebih mudah untuk dipahami, perjelas letak dari saintifiknya dari silabus media pembelajaran Mobuya, arahkan kemampuan berpikir tingkat tinggi atau HOTS (Higher, Order, Thinking, Skills) ditampakkan dalam silabus sehingga kemampuan yang ingin dicapai terlihat. Saran dan komentar dari ahli materi akan dipertimbangkan dalam mengimplementasikan media pembelajaran Mobuya di sekolah dasar. Hasil validasi ahli materi pada lembar validasi RPP sesuai dengan kriteria valid atau layak. Selain memberikan hasil validasi RPP, ahli materi juga memberikan komentar dan saran untuk RPP yang digunakan yaitu RPP saintifik harus ditampakkan. RPP yang akan diberikan kepada peserta didik terlihat belum tampak dalam langkah pembelajaran yang akan diajar.

Validasi media yang diberikan kepada validator ahli media pembelajaran menunjukan kriteria baik sehingga dapat dilanjutkan, tetapi dengan beberapa bagian yang harus direvisi. Saran dari validator berupa hasil dan gambar ada yang kecil dan kurang jelas alasan yang diberikan untuk perbaikan karena kurang diperbesar dan kurang diperjelas pada gambar saran perbaikan diberikan oleh validator berupa perbaiki. Saran dari ahli media dipertimbangkan dalam implementasi media pembelajaran Mobuya. Media yang dikembangkan termasuk dalam kategori masih perlu untuk diperbaiki sesuai dengan saran validator. Kemudian hasil dari validasi yang dilkukan oleh validator media pembelajaran tersebut disesuai

kan dengan. Media yang dikembangkan termasuk dalam kategori layak untuk diterapkan, namun lakukan revisi kecil.

Hasil penilaian angket yang diberikan kepada guru pada 22 Januari 2019 menunjukkan media pembelajaran dapat atau layak untuk diberikan kepada peserta didik untuk dibelajarkan atau dikenalkan kepada peserta didik. Persentase tersebut jika dikonversikan memperoleh kriteria layak dapat dipergunakan tanpa perbaikan. Hasil penilaian angket yang diberikan kepada guru pada tanggal 23 Januari 2019 diperoleh sebesar 96,25\%. Persentase tersebut jika dikonversikan memperoleh kriteria sangat layak dapat dipergunakan tanpa perbaikan. Jadi, dapat disimpulkan bahwa media pembelajaran Mobuya sangat layak diterapkan pada sekolah dasar.

Berdasarkan uji coba yang telah dilakasanakan pada proses pembelajaran didapatkan pada media pembelajaran Mobuya peserta didik masih susah untuk membuka kartu media pembelajaran Mobuya sehingga masih perlu untuk disederhanakan kembali. Selain itu, peserta didik masih mengeluhkan untuk materi yang diberikan terlalu panjang. Media pembelajaran Mobuya juga terdapat beberapa kendala dalam proses penerapannya, salah satunya siswa masih tidak fokus pada media pembelajaran. Namun, secara keseluruhan media pembelajaran ini sudah mampu memberikan pembelajaran yang menyenagkan dan bermakna.

\section{PEMBAHASAN}

Media pembelajaran Mobuya dikembangkan dalam rangka menciptakan pembelajaran tematik di sekolah dasar yang menyenangkan dan bermakna. Belajar melalui kegiatan nyata peserta didik dapat memperoleh pengalaman belajar yang bermakna dan menyenangkan. Media pembelajaran mampu menjembatani pembelajaran peserta didik (Majid, 2017). Dengan demikian, tercipta pembelajaran yang menyenangkan, aktif, dan kreatif. Penerapan media pembelajaran Mobuya didasarkan pada spesifikasi produk yang dikembangkan berupa pengenalan keberagaman budaya daerah Sanggau. Media pembelajaran Mobuya dikategorikan sebagai media permainan papan (board game). Permainan papan (board game) merupakan alternatif media pembelajaran karena dengan bermain sesuai dengan karakteristik peserta didik (Hedman, 2011). Berdasarkan penelitian Latief (2017) melalui media pembelajaran papan permainan papan (board game) memberikan pembelajaran menyenangkan sehingga tidak monoton. Melalui media pembelajaran Mobuya sesuai dengan karakteristik peserta didik karena dengan permainan papan (board game) sehingga akan memudahkan peserta didik untuk memahami pembelajaran di sekolah.

Penggunaan kartu pada proses kegiatan pembelajaran memberikan pembelajaran yang bermakna dan menguatkan konsep belajar peserta didik. Hal ini sejalan dengan temuan Oktavianti \& Ratnasari (2017) kartu-kartu pada media pembelajaran permainan papan (board game) dapat menciptakan pemahaman peserta didik dalam memahami konsep pembelajaran tematik untuk mengenalkan keberagaman budaya. Akan tetapi, peserta didik merasa bosan dan jenuh karena penggunaan kartu yang beragam. Untuk mengatasi rasa bosan dan jenuh, sebaiknya permainan kartu dibuat lebih sederhana agar pembelajaran lebih joyfull learning.

Pada pembelajaran tematik dengan media pembelajaran Mobuya dapat menciptakan pembelajaran yang menyenangkan. Hal tersebut dikarenakan belajar sambil bermain yang membuat siswa tidak merasa bosan. Selain itu, pada saat proses uji coba lapangan yang dilakukan oleh peneliti terlihat peserta didik bergembira belajar sambil bermain dengan media pembelajaran. Pernyataan tersebut sesuai dengan pendapat Majid (2017) melalui belajar sambil bermain dapat menciptakan belajar yang menyenangkan untuk peserta didik. Hal ini sejalan dengan prinsip belajar yaitu belajar sambil bermain dimana dapat menimbulkan suasana yang menyenangkan bagi peserta didik saat proses pembelajaran.

Media pembelajaran Mobuya dirasakan efektif untuk pengenalan budaya bangsaku. Lebih lanjut, Syamsijulianto (2020) menjelaskan bahwa media pembelajaran Mobuya menjadi solusi dalam mengenalkan keragaman budaya negeriku di sekolah dasar. Selain itu, media pembelajaran Mobuya mampu meningkatkan kemampuan kognitif, afektif, dan psikomotorik peserta didik. Media pembelajaran Mobuya yang dilakukan sambil bermain dan belajar sehingga lebih memberikan kekuatan dan pemahaman kepada peserta didik dalam membelajarkan materi keragaman budaya bangsaku (Syamsijulianto, 2020b). Jadi, dapat disimpulkan bahwa media pembelajaran Mobuya dapat dijadikan alternatif yang mampu mengembangkan kemampuan kognitif, afektif, dan psikmotorik. Melalui pembelajaran Mobuya juga peserta didik tidak hanya belajar tentang arti keragaman, tetapi juga arti 
kebersamaan. Berdasarkan hasil penelitian dapat disimpulkan bahwa media pembelajaran Mobuya dapat dijadikan alternatif media pembelajaran yang menyenangkan sehingga pembelajaran yang dilaksanakan menjadi aktif dan kreatif. Selain itu, melalui media pembelajaran Mobuya, peserta didik mampu meningkatkan keterampilan, sikap, aktivitas belajar, kesatuan, persatuan, dan daya fantasi.

\section{SIMPULAN}

Hasil validasi analisis terhadap penelitian media pembelajaran Mobuya, pada validasi materi diperoleh 92,50\% dengan kategori sangat layak, selanjutnya untuk validasi silabus diperoleh 92, 30\% dengan kategori sangat layak, validasi terhadap RPP diperoleh 93, 33\% dengan katergori sangat layak, media pembelajaran pertama diperoleh 70, 83\% dengan kategori cukup layak selanjutnya untuk validasi yang kedua diperoleh 74, 19\% dengan kategori cukup layak. Jika dilihat dari aspek peserta didik media pembelajaran efektif sebagai media pembelajaran ini berdasarkan pengamatan berdasarkan angket bahwa media pembelajaran efektif untuk diterapkan. Jika dilihat berdasarkan aspek kurikulum bahwa media pembelajaran sesuai dengan kompetensi dasar dan tujuan pembelajaran ini dapat dilihat dari uji validasi terhadap materi oleh ahli. Selanjutnya, bila dilihat dari aspek penilaian bahwa media pembelajaran dapat menjadi alternatif media pembelajaran karena mampu memberikan pembelajaran yang menyenagkan dapat dilihat dari hasil pretest dan posttest yang telah dibuat.

Hasil analisis terhadap posttest terhadap media pembelajaran bahwa nilai posttest sebesar 0.1520 dengan probabilitas 0.192 terlihat bahwa pada hasil posttest jauh diatas $\alpha=0.05$. Jika hipotesis nol tidak dapat ditolak maka data tersebut terditribusi normal. Jadi, dapat disimpulkan bahwa media pembelajaran dilihat dari hasil posttest terdistribusi normal atau hipotesis nol tidak dapat ditolak dengan arti bahwa terdistribusi normal. Selanjutnya, dilihat dari uji beda diketahu dari hasil analisis terhadap pretest dan posttest bahwa nilai signifikansi 2 tailed (sig. 2- tailed) sebesar $0,000<0,05$, maka dapat disimpulkan bahwa terdapat perbedaan variasi nyata antara hasil belajar dengan menggunakan media pembelajaran Mobuya pada pembelajaran tematik pada data pretest dan posttest. Melalui media pembelajaran Mobuya memliki taraf signifikasi terhadap hasil pembelajaran sehingga dapat disimpulkan bahwa dengan media pembelaran mampu meningkatakan hasil belajar serta dapat dijadikan media pembelajaran. Media pembelajaran dapat disimpulkan layak untuk digunakan pada proses pembelajaran.

Pada proses penerapan media pembelajaran Mobuya masih didapat beberapa kendala yang perlu untuk dilakukan perbaikan (1) pengaturan posisi kelompok sebaiknya harus diatur sebelum pelaksanaan pembelajaran dengan media pembelajaran Mobuya; (2) pengaturan waktu yang harus diperhitungkan sehingga proses pembelajaran dapat dilaksanakan dengan efisien; (3) kartu yang digunakan pada media pembelajaran masih perlu untuk dilakukan revisi berupa lebih mengenalkan keragaman budaya yang ada di daerah; (4) penggunaan media pembelajaran di dalam kelas harus lebih memahami karakteristik peserta didik yang ada pada tempat yang akan diterapkan; (5) pengaturan jadwal yang akan digunakan; (6) sebaiknya media pembelajaran Mobuya dilakukan dengan bermain peran; (7) materi sebaiknya dipaparkan sedikit pada proses pembelajaran untuk memberikan apersepsi pada peserta didik.

\section{DAFTAR RUJUKAN}

Asist, R., \& Sezer, B. (2013). Integrating Technology into Classroom: The Learner-Centered Instructional Design. International Journal on New Trends in Education and Their Implications, 4(4),134-144.

Branch, R. M. (2009). Instructional Design: The ADDIE Approach. Springer. https://doi.org/10.1007/978-0-387-09506-6

D'Astous, A., \& Gagnon, K. (2007). An Inquiry into the Factors that Impact on Consumer Appreciation of a Board Game. Journal of Consumer Marketing, 24(2), 80-89. https://doi.org/10.1108/07363760710737085

Fitriyawany. (2013). Penggunaan Media Permainan Monopoli melalui Pembelajaran Kooperatif pada Mahasiswa Fisika Fakultas Tarbiyah dengan Konsep Tata Surya. Jurnal Ilmiah Didaktika, 13(2), 223-239.

Halloran, R. O., \& Deale, C. (2017). Designing a Game Based on Monopoly as a Learning Tool for Lodging Development Designing a Game Based on Monopoly as a Learning Tool for Lodging Development. Journal of Hospitality \& Tourism Education, 22(3), 35-48. https://doi.org/10.1080/10963758.2010.10696983

Hedman, E. (2011). The Frustration of Learning Monopoly: The Emotional Tension of Entering a New Game Encounter. The Ethnographic Praxis in Industry Conference, Boulder, 2001, 18-21.

Latief, M. (2017). Pengembangan Permainan Ular Jarra sebagai Media Pembelajaran Pada Materi Pokok Asam-Basa. Indonesian Journal of Educational Studies, 20(2), 101-107.

Majid, A. (2017). Pembelajaran Tematik Terpadu. Bandung: Remaja Rosdakarya.

Oktavianti, I., \& Ratnasari, Y. (2017). Permainan Monopoli Engklek Jelajah Budaya Pati untuk Pembelajaran Tematik. Seminar Nasional Pembelajaran Bahasa dan Sastra Indonesia Berbasis Kearifan Lokal dalam Pembentukan Karakter Bangsa, 63-71.

Park, J. W. (2017). Hybrid Monopoly: A Multimedia Board Game that Supports Bidirectional Communication between a Mobile Device and a Physical Game Set. Multimedia Tools and Applications, 76(16), 17385-17401. https://doi.org/10.1007/s11042-017-4589-x 
Retnawati, H., Munadi, S., Arlinwibowo, J., \& Wulandari, N. F. (2017). Teachers' Difficulties in Implementing Thematic Teaching and Learning in Elementary Schools. The New Educational Review, 48(2), 201-212. https://doi.org/10.15804/tner.2017.48.2.16

Suhendrianto. (2017). Pengembangan Media Pembelajaran Monopoli Tematik untuk Meningkatkan Motivasi Belajar Siswa Kelas IV MIN Tegalasri Kec. Wlingi Kab. Blitar. Tesis tidak diterbitkan. Universitas Islam Negeri Maulana Malik Ibrahim, Malang.

Sukini. (2012). Pembelajaran Tematik di Sekolah Dasar Kelas Rendah dan Pelaksanaannya. Magistra, 24(82), 59-69.

Susanto, A. (2014). Pengembangan Pembelajaran IPS di Sekolah Dasar. Jakarta: Kencana.

Syamsijulianto, T. (2020a). Media Pembelajaran Mobuya untuk Pembelajaran Keragaman Budaya. Jurnal Penelitian dan Pengembangan Pendidikan, 4(1), 10. https://doi.org/10.23887/jppp.v4i1.23971

Syamsijulianto, T. (2020b). Penerapan Media Pembelajaran Mobuya pada Indahnya Keragaman Budaya Bangsaku di Sekolah Dasar. Briliant: Jurnal Riset dan Konseptual, 5(2), 209. https://doi.org/10.28926/briliant.v5i2.449

Wangid, M. N., Mustadi, A., Erviana, V. Y., \& Arifin, S. (2014). Kesiapan Guru SD dalam Pelaksanaan Pembelajaran Tematik-Integratif pada Kurikulum 2013 di DIY. Jurnal Prima Edukasia, 2(2), 175-182. https://doi.org/10.21831/jpe.v2i2.2717

Yong, C. Y., Chew, K. M., Mahmood, N. H., \& Arifin, I. (2014). Image Processing Tools Package in Medical Imaging in MATLAB. International Journal of Education and Information Technologies, 6(3), 260-263. 